to the legislature, makes for reasonably prompt changes as circumstances develop.

Proposed Constitutional Amendment

The General Assembly in 1959 passed a constitutional amendment to change the method of selection and tenure of judges in Iowa. If approved in identical form during the current session of the legislature, it will be submitted to the voters in a special election in 1962. This amendment provides that the Governor appoint justices of the Supreme Court and district judges from a list of nominees selected by a nonpartisan representative commission, with the voters having the opportunity to remove an unsatisfactory judge in a noncompetitive election.

\title{
Conclusion
}

The courts of record in Iowa, with the possible exception of the early county courts, have been so administered as to merit the confidence of the people living within the state. The judges who have administered our courts, with few exceptions, have been persons of high character and of high intellectual and legal attainment. Consequently the courts of this state have generally been recognized as a division of our government in which great confidence has been placed. This confidence will be continued and merited if the individuals. who administer our courts will be ever mindful that they are custodians of a high trust, a trust that has developed throughout the years-a trust which, if well administered, will make for the preservation of our form of government.

\section{History of Cigarette Smoking}

Cigarette smoking is compartively a recent habit in the United States, being introduced in the early seventies. There were very few cigarettes manufactured until 1875 . . . . It originated among the lower classes of Russia, Poland and France, and for a long time was confined to the same classes in this country. Today it is recognized by students of social problems to be one of the most dangerous, degrading and demoralizing evils, and demands the early attention of our legislators toward its arrest.-Eighth Biennial Report of the Board of Health of the State of Iowa, 1895. 
Copyright of Annals of Iowa is the property of State of Iowa, by \& through the State Historical Society of Iowa and its content may not be copied or emailed to multiple sites or posted to a listserv without the copyright holder's express written permission. However, users may print, download, or email articles for individual use. 